\title{
A TESTKÉP MEGÍTÉLÉSE A RENDSZERES SPORTTEVÉKENYSÉGET VÉGZÖK KÖRÉBEN
}

\author{
Szücs Róbert Sándor - Pólya Éva - Szakály Zoltán
}

\section{Összefoglalás}

A testkép és az énkép viszonyulásának vizsgálata a szakirodalomban ismert és kutatott folyamat, de különösen a sportolók esetében csak az utóbbi évtizedben kapott nagyobb hangsúlyt. Jelen munkánkban a rendszeres sporttevékenységet végzök attitüdjeit elsösorban a testkép megitélésére, a sport jellegü tevékenység módjára és formájára koncentrálva vizsgáljuk. A kapcsolódó szakirodalom rövid áttekintése mellett saját primer kutatásunk eredményeit is bemutatjuk. Primer kutatásunkba olyan személyek kerültek bevonásra, akik rendszeres sporttevékenységet folytatnak, azaz legalább heti egy alkalommal sportolnak, önszántukból. Papiralapú és online kérdöives megkérdezést alkalmaztunk, melynek során a megkérdezettek attitüdjeire koncentráltunk elsödlegesen. A minta elemszáma 737 fó. Kutatásunk során megállapitottuk, hogy a szubjektiven érzékelt "normál” testalkat kategóriája egyre feljebb tolódik, és egyre inkább elfogadottá válik a túlsúly társadalmi megitélése. A fogyasztói társadalom által bemutatott ideális testképek következtében a vékony testalkatuiak vastagabbak, az erösebb alkattal rendelkezök vékonyabbak szeretnének lenni, vagyis máris fennáll egy olyan társadalmi probléma, amely gyakorta csak a fogyasztó, sportoló fejében létezik. Ez a jelenség alapvetöen megalapozhatja az étrend-kiegészitök térnyerését, hiszen ezek gyártói minden szegmentumnak kinálnak megoldást a valós vagy vélt problémájuk megoldására

Kulcsszavak: Testkép, Sport iránt elkötelezettek, Etrend-kiegészitök, Testalkat, Attitüd JEL: 130 


\title{
PERCEPTION OF BODY IMAGE AMONG PEOPLE ENGAGED IN SPORTS ON \\ A REGULAR BASIS
}

\begin{abstract}
Relationship between body and self-image is a well-known and frequently investigated process, however especially among athletes this area has been accentuated till the last decades in the literature. In our paper we investigate the attitude of people engaged in sports on a regular basis primary concentrating on perception of their body image, the type and form of sport activities. People who took part in our research are engaged in sports on a regular basis, they do sport activities at least once a week on their own free will. Paper assisted personal and online interviews were used, we were primary concentrating on the attitudes of the respondents. Size of the sample is 737 persons. During our research we came to the conclusion that subjectively perceived "normal" body shape category moving higher and the social judgement of overweight became more and more accepted. Owing to the ideal body shape presented by the consumer society slimmer people want to become thicker, people with a stronger shape want to become leaner. Hence a social problem come into being that only exist in the athlete's mind. This phenomenon can fundamentally base the headway of food supplements since the producers offer solutions to all segments' real or putative problems
\end{abstract}

Keywords: Body image, People engaged in sports on a regular basis, Food supplements, Body shape, Attitude

JEL: 130 


\section{Bevezetés}

Az ember saját testképéhez, és ebből kifolyólag önmagához, valamint az énképéhez való viszonyulását, annak negatív vagy pozitív irányultságát a szakirodalom ismeri és vizsgálja (Csabai, 2019), de az erre vonatkozó kutatások, források jellemzően az utóbbi 20 évben kezdtek szélesebb körben teret nyerni; különösen igaz ez a sportolókra vonatkozó kutatások esetében. A testkép értelmezése egy komplex és nehezen megérthető folyamat, hiszen az része az egyén önészlelésének és önértékelésének is (Peráčková és mtsai, 2018).

\section{Testkép és énkép}

A testkép és az egyén fizikai aktivitása egyértelműen összefüggést mutat, és jellemzően pozitív korreláció fedezhető fel köztük. A testkép jellemzően egy hosszabb időszak tekintetében is relatíve stabil (LeCompte et al., 2020), és különböző szinten áll kapcsolatban az önbecsüléssel, érzelmi stabilitással, étkezési szokásokkal, valamint a fizikaiaktivitás-mintázatokkal (Cash et al., 2004). Ugyanakkor több kutatás is alátámasztotta, hogy a fizikai aktivitás, a sport (Cronan-Scott, 2008) testképre gyakorolt hatása csak mérsékelt (Liechty et al., 2015), mégis ezek a tevékenységek a pozitív testkép népszerűsítésében fontos szerepet játszanak (Prichard-Tiggemann, 2005). A pozitív testkép értelmezése esetében a hangsúly a patológiai megközelítésről folyamatosan egy holisztikus, átfogó koncepció irányába tolódott el (Swami et al., 2018). Tágabb értelemben a pozitív testképet úgy definiálhatjuk, mint az egyén testére irányuló szeretetét, tiszteletét és elfogadását (Tylka - Wood-Barcalow, 2015). A pozitív testkép esetében az egyén elfogadja teste sajátosságait, akkor is, ha azok a társadalmi ideáloknak ellentmondanak, a hangsúlyt inkább a test funkcionalitására helyezi az esztétikummal szemben. Jellemzően a pozitív információk befogadásra, míg a negatívak megtagadásra vagy átkeretezésre kerülnek (Tylka, 2011, 2012). A pozitív testképpel kapcsolatosan számos pozitív asszociáció él, mint a jólét számos formája, többek között az optimizmus, a pozitív érzések, az élettel való elégedettség vagy a szubjektív boldogság (Swami et al., 2018). A jólétnek multidimenzionális jellege van, elsősorban érzelmi, pszichológiai és társadalmi oldalról tudjuk megközelíteni. Amenynyiben ezeket együttesen vizsgáljuk, egy összetett mutatót kapunk, amely megmutatja, hogy az egyén élete mennyire tekinthető „rózsásnak” (Keyes, 2002). A testkép folyamatosan változik, ez egy életen át tartó folyamat, az azzal való elégedetlenség jellemzően a kor előrehaladtával nő, és fiatal felnőttkorban tetőzik, különösen jellemző ez a nők esetében (Littleton-Ollendick, 2003; Coelho et al., 2016), de - különösen a 18 év alatti - fiúk is érintettek (Leng, 2020). Ugyanakkor ezt a folyamatot számos tényező befolyásolhatja, senki nem születik negatív testképpel (Smolak, 2002). Leginkább a család, a kortárscsoportok, valamint a média gyakorolnak hatást 
a testképre. Mindemellett egyéb szociokulturális tényezők, mint az etnikai hovatartozás, a társadalmi státusz, a kultúra, a család, az iskolai körülmények, a normák vagy akár a kortárs csoportok nyomása is formálják az egyén testképét (Dewi-Bambang, 2019). Abban az esetben, ha az egyén által érzékelt, valamint ideálisnak tartott testkép között eltérés, illetve ellentmondás van, az a testképpel való elégedetlenséget eredményez. Ez a jelenség ráadásul kulcs rizikófaktornak tekinthető számos egészségügyi kérdésben, mint az evési rendellenességek vagy a fizikai aktivitás kerülése (Leng et al., 2020). Néhány kutató (Altabe, 1998; Wardle et al., 1993) is úgy véli, hogy kulturális, illetve etnikai különbségek is felfedezhetők a testképpel való elégedetlenség esetében. Összességében kézenfekvőnek tűnik, hogy a testképpel való elégedetlenség csökkentése érdekében a fizikai aktivitás hatékony lehet (Leng et al., 2020). Az egészségért történő mozgáshoz pedig pozitív képzet társul a nők és a férfiak önbecsülése szempontjából is (Peráčková et al., 2018).

\section{Testkép és a sport kapcsolata}

A testképpel való elégedetlenség megelőzésében, illetve enyhítésében a sportnak elsődleges szerepe van (Coelho et al., 2016). Ugyanakkor a fizikai aktivitás és a testkép közötti kapcsolatot az aktivitás típusa, illetve a szabadidős tevékenység tulajdonságai is befolyásolják. Arra vonatkozóan viszont, hogy mely aktivitástípusok segítik elö vagy inkább gátolják ezt a folyamatot, már jóval kevesebb kutatási eredmény áll rendelkezésünkre (Liechty, 2015). Egyébként sem könnyü az összefüggést, illetve annak jellegét megtalálni, hiszen egy nagyon komplex kapcsolatrendszerről van szó. Sok esetben befolyásoló tényező lehet az is, hogy a sportnak milyen a kapcsolata a kinézettel. Olyan sportok esetében, ahol az esztétikummal szoros a kapcsolat (pl. torna, tánc) nagyobb annak a valószínűsége, hogy a testkép negatív, míg a megjelenésre kevésbé koncentráló sportok esetében (pl. kosárlabda) ez nem annyira jellemző (Liechty, 2015). Prichard és Tiggemann (2008) vizsgálatai azt mutatták, hogy bizonyos esetekben a fizikai aktivitás növekedésével a testképpel való elégedetlenség is nő. Felnőtt nők szembesülnek sokszor azzal az ellentmondással, hogy a jól teljesítő test megbecsülésének örvend, mert az erős és gyors, viszont a társadalmilag idealizált norma szerint a test sovány és karcsú (Lunde és Gattario, 2017). Ugyanakkor a sportolás meg is védheti az egyént a folyamatos testfelügyelettől, amennyiben a társadalmi környezet a funkcióra és a teljesítményre koncentrál inkább a megjelenés helyett (Slater-Tiggemann, 2011; Sabiston et al., 2020). Érdekes, hogy a nyugati kultúrákban egyre inkább az izmos, tónusos testábrázolás jellemzon, így a nők muszkulárisabb megjelenése annak köszönhető, hogy a társadalom nagyobb hangsúlyt helyez a fizikai aktivitásra, mint az ideális életmód részére (Tosseli-Stiga, 2017). A negatív testkép hatással van arra, hogy valaki a fizikai aktivitás mellett teszi le a voksát (Putra et al., 
2019). Ilyen esetekben az egyének inkább egyedül vagy kevés emberrel edzenek, nem nyilvános helyen. Ennek elsődleges oka a szégyenérzet, félelem mások bírálatától és az alacsony testképmegítélés. Elsősorban ezért kerülik a zsúfolt edzőhelyeket, különösen igaz ez azokra, akik tartanak mások bírálatától (Brudzynski-Ebben, 2010). A nemek között eltérés figyelhető meg a motiváció tekintetében is: a nők inkább társadalmi nyomásra kezdenek el edzeni, azért, hogy elérjék az ideálisnak tartott testformát, míg a férfiak inkább személyes örömszerzés céljából mennek le az edzőterembe. Abban az esetben is inkább negatív testkép figyelhető meg, ha valaki elsődleges motivációja az edzés során a súlyvesztés. Mégis megfigyelhető, hogy még abban az esetben is, ha valaki túlsúlyosnak gondolja magát, egyértelmüen nem fedezhető fel kapcsolat az edzés iránti elkötelezettség irányába (Fountoulakis-Grogan, 2014). Ugyanakkor azt is láthatjuk, hogy az edzés nem minden esetben csökkenti a negatív testkép megítélést (Putra et al., 2019). A fizikai aktivitás a nyugati kultúrákban a testtel kapcsolatos önbecsülés tekintetében fontos szerepet játszik: a tónusos test azért kívánatos, mert ez része annak, ahogy az egyén magát mások irányába prezentálja (Cambell-Hausenblas 2011; Kruger et al.. 2008; Coelho et al., 2015; Schmalz 2007). A pozitív testképészlelés hatékonyságtudathoz, önállósághoz, elfogadáshoz vezet, melyek szorosan kapcsolódnak az önbecsülés fejlődéséhez (Tosseli-Stiga, 2017). A kultúra és a faji hovatartozás is fejlettebb testképhez vezethet, amennyiben az adott kultúra a nagyobb testformát értékeli, illetve amennyiben széles skáláját elfogadja (Liechty, 2015).

\section{A fizikai (in)aktivitás és testkép kapcsolata}

Napjaink szakirodalma kiemelt hangsúlyt fordít a túlsúllyal, elhízottsággal küzdők problémáinak vizsgálatára. Az Európai Lakossági Egészségfelmérés (ELEF) 2014-es adatai szerint Magyarországon túlsúlyosnak és elhízottnak tekinthető a felnőttkorú lakosság több mint fele (54\%). A tanulmány adatai szerint a 18-34 éves férfiak 39,3\%-a, a 35-64 évesek 71,1\%-a, a 65 évnél idősebbek 72,1\%-a sorolható a túlsúlyos vagy elhízott kategóriák valamelyikébe. A nők esetében ezek az arányszámok sorrendben $23,4 \%, 52,8 \%$, illetve $65 \%$ (KSH, 2015a). A legfejlettebb országokat tömörítő szervezet, az OECD 2015-ös adatai szerint a férfiak 72\%-a, míg a nők 64\%-a sorolható a túlsúlyos vagy elhízott kategóriák valamelyikébe. Különösen súlyos a helyzet Magyarországon, ahol 2014-ben az átlagos túlsúlyossági ráta 62,3\% volt a felnőttkorú lakosság körében. A 15 év feletti nők 31,5\%-a, míg a férfiak 28,2\%-a elhízott a tanulmány adatai szerint. Ez a gyakorlatban azt jelenti, hogy a magyarországi adatok a negyedik legrosszabbak a világon, az Egyesült Államok, ÚjZéland, Mexikó mögött Magyarország következik a rangsorban; vagyis Magyarország a leginkább elhízott európai ország (OECD, 2017). A fizikai inaktivitásból származó 
túlsúlyosság és elhízottság visszaszorításában a fejlett országok rendre kudarcot vallanak, így érhető módon sokkal kisebb figyelmet kapnak azon szegmentum tagjai, akik tudatosan küzdenek a fizikai inaktivitás ellen, vagyis önszántukból sportolnak. Az Európai Unió lakosságának 27,6\%-a semmilyen fizikai aktivitást nem folytat. A magyar lakosság körében mért 49,8\%-os arány kifejezetten kedvezőtlen a 2017-es adatok szerint (EUROSTAT, 2019). A 2009-2010-ben Magyarországon végzett időmérleg-felvétel szerint egy átlagos 10 és 84 év közötti lakos naponta átlagosan 139 percet töltött tévénézéssel, ugyanakkor csak hét perc jutott a sportolásra $(\mathrm{KSH}$, 2018). Az ELEF részletes adatait tartalmazó kimutatásokból látható, hogy a 15-34 éves korú férfiak 28,5\%-a, míg a 35-64 éves korúak 10\%-a (férfiak átlagosan 14,8\%) végez a WHO ajánlásának megfelelő sporttevékenységet. Az arány a nők esetében rendre 20,2\% és 8,2\% (nők átlagosan 10,2\%) (KSH, 2015b). A WHO 2011-es ajánlása szerint hetente összesen legalább 150 perc közepes intenzitású vagy 75 perc erős intenzitású fizikai aerob tevékenységre van szükség ahhoz, hogy a mozgás előnyei érvényesüljenek. Annak ellenére, hogy a szakirodalom kiemelt figyelmet fordít a túlsúllyal, elhízottsággal küzdők problémáira, nem csupán a testmozgás szempontjából inaktívak csoportjának vannak nehézségei, hanem a fizikailag aktívak fejében is vannak kételyek, például saját testalkatuk kapcsán. Annak kapcsán, ahogyan saját magukat látják a tükörben. Bár a megkérdezettek fizikai paraméterei, testmagassága, testsúlya alapján számított BMI-érték meghatározza a vizsgálatban résztvevők testalkatát, ez az objektív kategória korántsem biztos, hogy egybeesik a megkérdezett fejében élő, vagyis a tükörben látott, szubjektív testképpel. A fogyasztó fejében élő emlékkép saját gyermekkori testalkatáról befolyásoló hatást fejthet ki: az a felnőtt korú személy, aki gyermekkorában sovány, túlsúlyos vagy éppen elhízott volt, az gyakorta ugyanazt a vékony, túlsúlyos vagy elhízott gyermeket látja a tükörben, aki annak idején volt, persze idősebb kiadásban. A jelenség akkor is megfigyelhető, ha ennek már valós alapja nincs. Ábrahám és munkatársai (2017) tanulmányukban leírják, hogy a szakirodalomban egyre nagyobb figyelmet kapnak a különböző a testképzavarok. A fogyasztói társadalmakban a testtudatosság és a soványság kultuszát éljük. A média által közvetített túl sovány vagy túl izmos ideálok igen erőteljesen hatással vannak a gyerekek és a serdülők testképére is. A testkép alakulására ható tényezők nem csupán a média különböző csatornáin - például mesefilmek -, hanem játékokon (például Barbie, G. I. Joe) keresztül is érvényesülnek (Smolak 2002; Smolak 2011; Bird et al., 2013).

\section{Anyag és módszer}

Kutatómunkánk során egy olyan szegmentum attitűdjeit mértük fel a fentebb részletezett kérdéskörökben, úgymint a testkép megítélése, a sport jellegű tevékenység 
módja és formája, az étrend-kiegészítők fogyasztási szokásai kapcsán, amely vélelmezhetően más megkérdezettektől magasabb szintű tudatosságot mutat fel egészségének megőrzése érdekében. Ők azok, akik a magyar társadalom többségével ellentétben rendszeres sporttevékenységet folytatnak, önszántukból. Primer kutatásunk célcsoportjának kiválasztásakor az önkényes és tudatos kiválasztás eszközével éltünk. Vizsgálatunk célcsoportját csak olyan személyek alkották, akik rendszeres sporttevékenységet folytatnak, azaz legalább heti egy alakommal sportolnak, önszántukból. A mintának nem lehettek elemei azon személyek, akik kötelező jelleggel (pl. testnevelésóra keretei között) folytattak sporttevékenységet, még akkor sem, ha ez hetente több alkalommal is megvalósul (van heti négy testnevelésórája a megkérdezettnek). Ez természetesen nem zárta ki a mintából azokat, akik a kötelező sporttevékenység (pl. testnevelésóra) mellett szabad akaratukból is sportolnak (pl. eljár kézilabdaedzésre, fut stb.). Miután a megkérdezett megfelelt az önkéntes alapon végzett rendszeres sporttevékenység feltételének, ezután a kiválasztás során a hólabda módszer dominált. Az adatok felvételét a Debreceni Egyetem Szolnok Campusának hallgatói segítették, akik a kérdőív kitöltetésében nyújtottak segítséget. A minta elemszámának és területi kiterjedésének növelése érdekében sportegyesületeket, edzőtermeket stb. kerestünk meg elektronikus úton, akik tagjaik számára elérhetővé tették kérdőívünket. Kutatásunkba a sporttevékenységek legszélesebb körét bevontuk. A jógától elindulva, a lovagláson, tornán, futáson, küzdősportokon át, szinte valamennyi sportág képviseltette magát. A csoportosítás, összevonás után is 21 féle sportágat/tevékenységet különítettünk el, melyből következően kijelenthetjük, hogy mintánk semmiképpen sem nevezhető egysíkúnak. A megkérdezett sportolók körében a legnépszerübb sportágak a következők voltak: súlyzós edzés (34,5\%), futás (29,4\%), labdasportok $(18,9 \%)$, kerékpározás $(15,9 \%)$, úszás $(9,9 \%)$, saját testsúlyos edzés $(8,8 \%)$, küzdősportok $(6,0 \%)$, aerobik $(5,8 \%)$. A labdasportok közül a labdarúgás mutatja fel a legnagyobb népszerűségi arányt a maga 8,1\%-os értékével.

Az attitűdök vizsgálata kapcsán papíralapú és online kérdőíves felmérést folytattunk le Magyarországon, 737 fós fogyasztói minta bevonásával. A kutatásban való részvétel önkéntes és anonim volt. Kérdőívünk elérhető az alábbi linken: https://bit.ly/foodsupplement_questionnaire. A felmérés 15 megyére terjedt ki. A mintában a legnagyobb arányban a Jász-Nagykun-Szolnok megyei kitöltők voltak (36,5\%), de Pest megye (18,6\%), Bács-Kiskun megye (14,0\%), Csongrád megye $(12,2 \%)$, Békés megye $(6,1 \%)$ lakosai is képviseltették magukat. A falusi kitöltők aránya $13,8 \%$, a városi kitöltőké 53,9\%, a megyeszékhelyen élők 26,3\%-ban, a fövárosiak 6,0\%-ban voltak jelen a mintában. A megkérdezettek 59,0\%-a átlagosnak, 28\%-a kis mértékben átlag felettinek ítélte családja anyagi helyzetét. A kitöltésre 2019. november 6. és 2019. december 13. között volt lehetőség. A mintában a 14 életévtől a 72 évig bezárólag, minden korcsoportból voltak kitöltők. A minta átlagos életkora: 30,2 életév, szórása 11,7 év. A módusz értéke 20, míg a medián értéke 27 
év. Szekunder forrásokból ismert (KSH, 2015b), hogy a korcsoportok mentén elörehaladva egyre alacsonyabb a sportolók aránya, melyhez mintánk is alkalmazkodik. Mintánk életkor szerinti megoszlását az alábbi 1. számú ábrával illusztráljuk, mely ábrán elhelyezett trendvonal csupán a szemléltetést segíti.

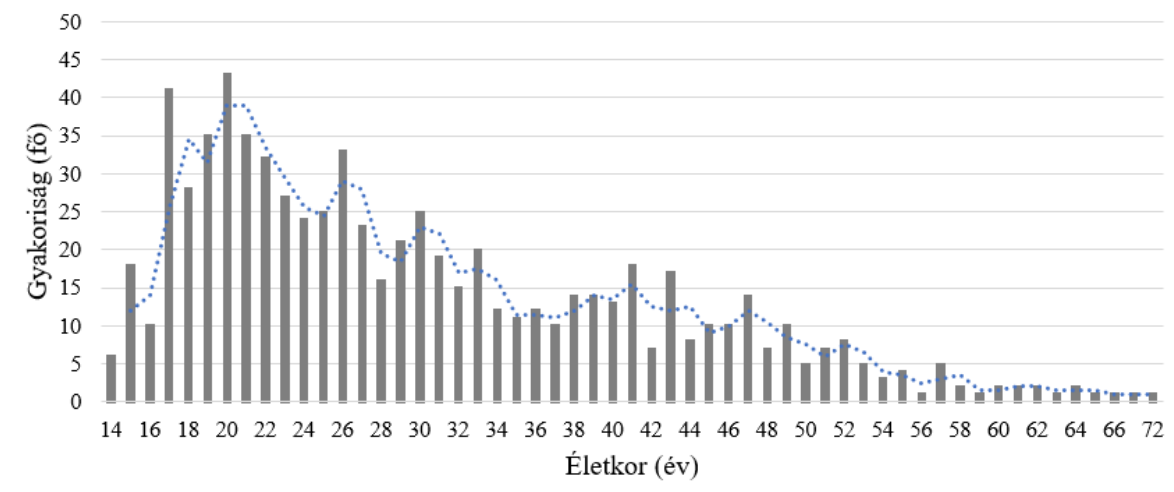

1. ábra: A minta életkor szerinti megoszlása $(\mathrm{n}=737)$ Forrás: Saját kutatás, 2020.

Fenti 1. ábra jól szemlélteti, hogy a mintába gyermekkorú személyt nem vontunk be. A megkérdezettek életkorát semmiképpen sem jellemezhetjük a serdülő jelzővel, ugyanis a megkérdezettek 89,2\%-a legalább 18 éves a mintában. A mintában a nők aránya $47,5 \%$, a férfiak aránya 52,5\%. Szekunder adatokból (KSH, 2015a) megállapítható volt, hogy a gyaloglás, kerékpározás, sportolás együttes figyelembevételével számított mutató alapján a magyar lakosságnak csak kis része mozog az ajánlásoknak megfelelő mennyiségben (a férfiak 14,8\%-a, a nők 10,2\%-a). Természetesen nincs olyan nemzeti lista, amely azon emberekről tartalmazna információkat, akik önszántukból, legalább heti egy alkalommal sportolnak, önkéntes alapon. Ebből következően nem mondhatjuk azt, hogy kutatásunk reprezentatív, ugyanakkor a mintánkban több férfi van, mint nő, ami megfelel a KSH ilyen jellegű adatainak. Ebből következően a minta nem szerinti megoszlása jól tükrözi a sokaság nem szerinti megoszlását. Az érettségivel rendelkezők aránya a legmagasabb a mintában (42,4\%), majd őket követi a felsőfokú végzettséggel rendelkezők aránya (37,5\%), szakmunkás végzettséggel a megkérdezettek 7,9\%-a, míg általános iskolai végzettséggel a megkérdezettek 10,7\%-a rendelkezett. A megkérdezett sportolók adataiból számított BMI-értékek rendkívül közel állnak a WHO iránymutatásának megfelelő mennyiségű sporttevékenységet végzők testalkat szerinti megoszlásához, vagyis a mintánk testalkat szerint jól tükrözi a WHO által meghatározott és leírt sokaságot.

A kérdőív egyéb személyes adatokra, úgymint testsúly, testmagasság is kitért, melyeket a BMI kiszámításához használtunk fel. A kérdőív kvantitatív kutatási jellegéből 
fakadóan egyéni mérésekre (testsúly mérése mérleggel, testzsírszázalék mérése stb.) nem volt lehetőségünk. A BMI-t a szakirodalomban általánosan elfogadott módon számoltuk, vagyis a megkérdezett kilogrammban kifejezett testtömegét osztottuk a méterben mért magasságának négyzetével. Az így kapott értéket a WHO által ajánlott testsúlyosztályozási táblázat segítségével értékeltük (sovány, normál, túlsúlyos, elhízott). A BMI-t mint mutatószámot több bírálat is éri napjainkban. Vizsgálatunk során azért ezt a mutatószámot alkalmaztuk, mert - bár vannak gyengeségei - ennek a leginkább elterjedt a használata, illetve a megkérdezettek leginkább erről a mutatószámról rendelkeznek információval. Az adatok feldolgozása során statisztikai módszereket alkalmaztunk SPSS 23.0 program és Microsoft Excel 2016 segítségével. A jelen tanulmányban is említett Cramer-féle asszociációvizsgálati módszert kereszttáblák ismérveinek összefüggés-vizsgálatainál használhatjuk. Az ismérvek közötti sztochasztikus kapcsolatokat az SPSS programcsomagban a Cramer-féle asszociációs együtthatóval (C) vizsgálhatjuk. A Cramer-féle asszociációs együttható értéke 0 és 1 közötti értéket vehet fel. A 0 érték azt jelenti, hogy a két ismérv között nincs kapcsolat, vagyis az ismérvek függetlenek egymástól, míg az 1 érték az ismérvek között fennálló függvényszerü kapcsolatot írja le. A mutató számításának alapja a függetlenség feltételezésével számított gyakoriságokon nyugszik.

\section{Eredmények}

Kutatásunk során vizsgáltuk azt, hogy a rendszeres sporttevékenységet végzők menynyire látják reálisan saját testalkatukat, vagyis a megkérdezett fejében élő testkép hogyan viszonyul a megkérdezett adataiból (testsúly és testmagasság) számított BMIkategóriákhoz. Szakirodalmi forrásokra támaszkodva feltételezhető a korreláció a testkép és testalkat között (a normál testalkat sokkal inkább pozitív testképpel, míg a túlsúly és elhízottság sokkal inkább negatív testképpel párosul). A kutatás során összevetettük a megkérdezett által említett testképet (önbevallásos BMI - a sporttevékenységet végző fejében élő szubjektív testkép) a megkérdezett adataiból (testsúly, testmagasság) számított BMI alapján realizálódó, a WHO által ajánlott testsúlyosztályozási táblázatban meghatározott testalkattal (sovány, normál, túlsúlyos, elhízott). Szakirodalmon alapuló feltételezésünk szerint a megkérdezett fejében élő testkép megítélését befolyásolhatja a megkérdezett emléke saját gyermekkori testalkatáról. A részletes adatokat az 1. táblázat tartalmazza, mely táblázatot kiegészítettük az ELEF (2014) adatai alapján meghatározott testalkati kategóriák megoszlásával (3. sor), valamint a WHO iránymutatásának megfelelő mennyiségü sporttevékenységet végzők testalkati kategóriájának megoszlásával is (4. sor). 
1. táblázat: Az önbevallásos és mért BMI-kategóriák összefüggései a különböző referenciaértékekkel $\mathbf{n}=737$ )

\begin{tabular}{|l|r|r|r|r|r|}
\hline Megenevezés & Sovány & Normál & Túlsúlyos & Elhízott & Összesen \\
\hline $\begin{array}{l}\text { A megkérdezettben } \\
\text { élö kép saját, } \\
\text { gyermekkori testalka- } \\
\text { táról }\end{array}$ & 29,0 & 53,7 & 11,5 & 5,9 & 100,0 \\
\hline $\begin{array}{l}\text { A megkérdezett } \\
\text { véleménye saját, } \\
\text { jelenlegi testalkatról } \\
\text { (önbevallásos BMI) }\end{array}$ & 4,9 & 78,4 & 14,3 & 2,3 & 100,0 \\
\hline $\begin{array}{l}\text { A megkérdezett BMI- } \\
\text { értéke alapján katego- } \\
\text { rizált testalkat } \\
\text { (számított BMI) }\end{array}$ & 3,9 & 55,0 & 30,7 & 10,4 & 100,0 \\
\hline $\begin{array}{l}\text { ELEF (2014) alapján } \\
\text { mért testalkati } \\
\text { kategóriák megoszlása } \\
\text { Magyarországon }\end{array}$ & 3,4 & 42,5 & 33,2 & 20,9 & 100,0 \\
\hline $\begin{array}{l}\text { A WHO } \\
\text { iránymutatásának } \\
\text { megfelelő mennyiségü } \\
\text { sporttevékenység } \\
\text { végzők testalkati } \\
\text { kategóriáinak } \\
\text { megoszlása }\end{array}$ & 5,6 & 56,1 & 28,6 & 9,7 & 100,0 \\
\hline
\end{tabular}

Forrás: Saját kutatás, 2020.

Fenti 1. táblázat alapján jól látható, hogy a megkérdezettek adataiból számított BMIértékek és -kategóriák rendkívül közel állnak a WHO iránymutatásának megfelelő mennyiségü sporttevékenységet végzők testalkat szerinti megoszlásához, vagyis a mintánk testalkat szerint jól tükrözi a WHO által meghatározott és leírt sokaságot. Míg a megkérdezettek adataiból számított BMI-értékek és -kategóriák rendkívül közel állnak a WHO értékeihez (vagyis a mintánk testalkat szerint jól reprezentálja a WHO adatait), addig nagy eltérés mutatkozik a megkérdezettek adataiból számított és az önbevallásos testalkati kategóriák között. A kérdésekre választ adó 732 főből 289 fónél, azaz a megkérdezettek 39,5\%-nál mutatkozik eltérés az önbevallásos BMI és a megkérdezett adataiból számított BMI kategóriája között. Az eltérést felmutatók 94,2\%-a alábecsülte saját testalkatának kategóriáját a számításokon alapuló BMI-kategóriához képest. Szükséges megjegyezni, hogy a BMI azon sportolóknál, akik az 
átlagosnál nagyobb zsírmentes izomtömeggel rendelkeznek, pontatlan eredményt adhat, indokolatlanul túlsúlyt jelezhet. Ez a BMI-nek mint mutatószámnak egyfajta gyengesége, amely pontatlanságot igyekeztünk vizsgálatunkban oly módon korrigálni, hogy figyelembe vettük a megkérdezett izomzatának fejlettségi szintjét. Mintánkban a BMI gyengesége elméleti szinten 160 fónél jelentkezhet, ugyanis ők azok, akik saját bevallásuk szerint az átlagtól kis mértékben vagy jelentősen nagyobb izomtömeggel rendelkeznek. Feltételezve a leginkább kedvező esetet, vagyis kiszürve a mintából mindazokat, akik az átlagostól kis mértékben vagy jelentős mértékben fejlettebb izomzattal (zsírmentes izomtömeggel) rendelkeznek saját bevallásuk szerint, a kérdéses 160 fós szám 51 före redukálható le. Ebben, a legkedvezőbb elméleti esetben, mely vélhetően nem áll fenn, az objektív és szubjektív testkép a megkérdezettek 23,1\%-nál mutat eltérést. Becslésünk szerint a reális érték nagyságrendileg 30\% környékén mozoghat, vagyis igen jelentős eltérést mutat a sportolók saját fejében élő szubjektív testkép (önbevallásos BMI) az objektív kategóriától (a megkérdezett adataiból számított BMI alapján képződő testalkati kategória). Az 1. táblázat adataiból megállapítható, hogy a megkérdezett sportolók jelentősen alábecsülték a túlsúlyosság és elhízottság mértékét, elnézők saját testalkatuk kapcsán. Ez következhet az egyén erős énvédő mechanizmusának működéséből és abból is, hogy a túlsúlyosság és elhízottság egyre inkább elfogadottá válik össztársadalmi szinten (megváltozik a viszonyítási pont a megkérdezettek fejében, hogy mi számít normál, túlsúlyos és elhízott testalkatnak). Ha az eredményeket a megkérdezett neme szerint bontjuk, akkor megállapítást nyer, hogy a férfiak sokkal inkább elnézők saját túlsúlyosságukat és elhízottságukat illetően. A férfiak 16,6\%-nak él a fejében túlsúlyos vagy elhízott testkép saját magáról, ugyanakkor a megkérdezett sportolók adataiból számított BMI-kategória szerint ez az érték 54,6\% (WHO referenciaértéke 44,6\%, vagyis a mintánk férfi közössége még túlsúlyosabb is, mint a WHO-átlag). A nők 16,7\%-a látja saját testét túlsúlyosnak vagy elhízottnak, míg esetükben a testsúly és testmagassági adatokból számított BMI szerinti kategóriaérték 26,3\% (WHO referenciaértéke 27,6\%). Annak ellenére, hogy a férfiakat nagyobb arányban érinti a túlsúlyosság és elhízottság, kevésbé látják saját alkatukat problémásnak, mint a nők. Az eredményekből az is látható, hogy még a fizikailag aktívak esetében is jelentős eltérés mutatkozik a fogyasztó fejében élő szubjektív kép és a valós, számításokon alapuló objektív testalkat között. Az eltérések kételyek táptalajaként szolgálhatnak.

Kutatómunkánk során vizsgáltuk, hogy a megkérdezett sportolók emlékezetében élő kép saját gyermekkori testalkatukról képes-e befolyásoló hatást kifejteni a megkérdezettek jelenlegi testképének érzékelésére. Kereszttáblás analízissel az alábbi megállapításokat tettük:

- Azon sportolók, akik gyermekkori testalkatukra soványként emlékeztek vissza, ezen csoport tagjainak 33,2\%-a alábecsülte jelenlegi BMI-kategóriáját. A túlbecsülés aránya $4,3 \%$. 
- Azon sportolók, akik gyermekkori testalkatukat normál jelzővel illették, ezen csoport tagjainak 30\%-a alábecsülte, míg 4,6\%-a túlbecsülte saját jelenlegi BMI-kategóriáját.

- A gyermekkorban saját magukat túlsúlyosnak gondolók 49,4\%-a alábecsülte, míg 7,2\%-a túlbecsülte saját jelenlegi BMI-kategóriáját.

- A gyermekkorban saját magukat elhízottnak gondolók esetén $51,5 \%$ az alábecslés, míg $7 \%$ a túlbecslés aránya.

Pszichológiai szempontból érdekes annak összevetése, hogyan látom saját magam, illetve mit gondolok arról, hogy a társadalom tagjai hogyan látnak engem. Ezt a logikai gondolatmenetet, egyfajta projektív technikát, jelen kutatásunkban is alkalmaztuk. Vizsgálatunk kiterjedt annak összehasonlítására, hogy a megkérdezett sportolók mit gondolnak arról, hogy a társadalom más tagjai hogyan látják az ő testalkatukat. Az alábbi 2. táblázat tartalmazza az összevetés főbb irányszámait.

2. táblázat: A testalkat saját és vélelmezett társadalmi megítélése $(\mathrm{n}=737)$

\begin{tabular}{|l|r|r|r|r|r|}
\hline & \multicolumn{1}{|c|}{ Sovány } & Normál & Túlsúlyos & Elhízott & Összesen \\
\hline $\begin{array}{l}\text { Milyennek ítéli meg } \\
\text { saját, jelenlegi } \\
\text { testalkatát? }\end{array}$ & 4,9 & 78,4 & 14,3 & 2,3 & 100,0 \\
\hline $\begin{array}{l}\text { Mit gondol, hogyan } \\
\text { látják az Ön } \\
\text { testalkatát mások? }\end{array}$ & 9,0 & 77,1 & 11,9 & 2,0 & 100,0 \\
\hline
\end{tabular}

Forrás: Saját kutatás, 2020.

A 2. táblázatban lévő adatok részletes szűrése után az alábbi főbb megállapításokra jutottunk:

- Azon sportolók, akik jelenlegi testalkatukra soványként tekintenek, saját megitélésünk szerint az ő testalkatukat a társadalom más tagjai 72,2\%-ban soványnak, 27,8\%-ban normál testalkatúnak tartják.

- Azon sportolók, akik jelenlegi testalkatukat normál jelzővel illették, saját megítélésünk szerint az ő testalkatukat a társadalom más tagjai 7,0\%-ban soványnak, 90,4\%-ban normálnak, 2,3\%-ban túlsúlyosnak és 0,3\%-ban elhízott testalkatúnak tartják.

- Azon sportolók, akik jelenlegi testalkatukat túlsúlyos jelzővel illették, saját megítélésünk szerint az ő testalkatukat a társadalom más tagjai 28,8\%-ban normálnak, 66,3\%-ban túlsúlyosnak és 4,8\%-ban elhízott testalkatúnak tartják.

- Azon sportolók, akik jelenlegi testalkatukat elhízott jelzővel illették, saját megítélésünk szerint az ő testalkatukat a társadalom más tagjai 23,5\%-ban normálnak, 29,4\%-ban túlsúlyosnak és 47,1\%-ban elhízott testalkatúnak tartják. 
Fenti 2. táblázat rávilágít arra a jelenségre, hogy a szubjektíven érzékelt „normál” testalkat kategóriája egyre feljebb tolódik, és egyre inkább elfogadottá válik a túlsúly társadalmi megítélése. Annak ellenére, hogy a túlsúly szubjektív módon egyre inkább elfogadottá válik, ez természetesen orvosi, egészségügyi szempontból nincs így. Az, hogy a társadalom tagjai elnézőbbek a túlsúlyosság és elhízottság tekintetében („én is elhízott vagyok, te is elhízott vagy, mindenki elhízott, következésképpen nincs ezzel különösebb probléma”), ez természetesen nem jelenti azt, hogy a túlsúlyosságból és elhízottságból származó egészségügyi kockázatok, problémák, költségek csökkennének. Sőt, a helyzetbe való egyfajta társadalmi beletörődés csak tovább fokozza az elhízottságból és túlsúlyosságból származó problémák súlyát és mértékét.

Kutatásunkat kiterjesztettük a fogyasztó izomzatának objektív és szubjektív megítélésére is. Vizsgáltuk, hogy a megkérdezett sportolók hogyan látják saját izomzatuk fejlettségét, majd azt, mit gondolnak arról, hogyan ítélik meg a társadalom más tagjai az ő izomzatuk fejlettségét. A részletes adatokat az alábbi, 3. táblázat tartalmazza.

3. táblázat: Az izomzat fejlettségének társadalmi és saját megítélése $(\mathbf{n}=737)$

\begin{tabular}{|c|c|c|c|c|c|c|c|}
\hline & \multicolumn{5}{|c|}{$\begin{array}{c}\text { Mit gondol, hogyan látják az Ön izomzatának } \\
\text { fejlettségét mások? }\end{array}$} & \multirow[b]{2}{*}{$\Sigma$} \\
\hline & & $\begin{array}{l}\text { az } \\
\text { átlagos- } \\
\text { tól sok- } \\
\text { kal gyen- } \\
\text { gébb }\end{array}$ & $\begin{array}{l}\text { az } \\
\text { átlagos- } \\
\text { tól kissé } \\
\text { gyen- } \\
\text { gébb }\end{array}$ & normál & $\begin{array}{l}\text { az } \\
\text { átlagos- } \\
\text { tól kissé } \\
\text { erősebb }\end{array}$ & $\begin{array}{l}\text { az } \\
\text { átlagos- } \\
\text { tól sok- } \\
\text { kal } \\
\text { erősebb }\end{array}$ & \\
\hline 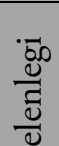 & $\begin{array}{l}\text { az átlagos- } \\
\text { tól sokkal } \\
\text { gyengébb }\end{array}$ & 3 & 1 & 2 & 1 & 0 & 7 \\
\hline 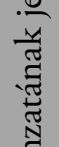 & $\begin{array}{l}\text { az átlagos- } \\
\text { tól kissé } \\
\text { gyengébb }\end{array}$ & 2 & 22 & 6 & 1 & 0 & 31 \\
\hline ๕్ี & normál & 6 & 18 & 227 & 19 & 4 & 274 \\
\hline 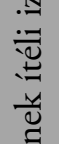 & $\begin{array}{l}\text { az átlagos- } \\
\text { tól kissé } \\
\text { erősebb }\end{array}$ & 3 & 3 & 72 & 206 & 22 & 306 \\
\hline 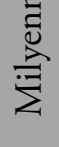 & $\begin{array}{l}\text { az átlagos- } \\
\text { tól sokkal } \\
\text { erősebb }\end{array}$ & 0 & 0 & 4 & 23 & 90 & 117 \\
\hline$\Sigma$ & & 14 & 44 & 311 & 250 & 116 & 735 \\
\hline
\end{tabular}

Forrás: Saját kutatás, 2020. 
Cramer-féle asszociációs együttható segítségével mértük a tényezők közötti kapcsolat szorosságát. Ideális esetben a mutatónak 1-es értéket kellene felvennie. Ebben az esetben az egyén ugyanúgy látja saját izomzatának fejlettségét, ahogyan megítélése szerint a társadalom tagjai látják őt. A mutató értéke 0,582 (Sig.: 0,000). Az érték arra utal, hogy a megkérdezettek úgy gondolják, hogy a társadalom más tagjai nem pontosan ugyanolyannak látják izomzatuk fejlettségét, mint amilyen az szerintük. A 3. táblázat átlójától jobbra található értékek azon a személyeket jelölik, akik alulértékelik és a szakirodalmi források alapján (lásd túl sovány vagy túl izmos ideálok felértékelődése) feltételezhetően elégedetlenek izomzatuk fejlettségével, mely egy negatív testkép kialakulásához vezethet. Ha az eredményeket a megkérdezett neme szerint bontjuk, akkor megállapítást nyer, hogy a férfiak 6,2\%-a értékeli alul / elégedetlen saját izomzatának fejlettségével. A nők esetében az elégedetlenek aránya még ennél is nagyobb mértékü, 9,2\%-os. A jelenséget marketingszempontból tovább gondolva és megközelítve, ezek a kételyek kihasználható üzleti lehetőséget jelentenek.

A fogyasztói társadalom által bemutatott ideális testképek következtében a vékony testalkatúak vastagabbak, izmosabbak, az erősebb alkattal rendelkezők vékonyabbak szeretnének lenni, vagyis máris fennáll egy olyan társadalmi probléma, amely gyakorta csak a fogyasztó, sportoló fejében létezik. Az étrend-kiegészítők gyártói minden szegmentumnak kínálnak megoldást a valós vagy vélt problémájuk megoldására. Fehérjét és izomtömeg-növelőt kínálnak a vékony testalkatúaknak, zsírégetőt a vélt vagy valós súlyfelesleggel küzdőknek.

\section{Következtetések, javaslatok}

A megkérdezett sportolók fejében élő szubjektív testkép az esetek mintegy 30\%-ában nem egyezett meg a megkérdezett sportolók jellemzőin nyugvó (testtömeg és magasság), számított BMI-kategóriákkal. Kutatásunk rávilágított arra, hogy a megkérdezett sportoló szubjektív testképét befolyásolhatja gyermekkori alkata is. A fogyasztói társadalmunkban hangsúlyozott testkultusz, a vállalati marketingkommunikáció által bemutatott, gyakorta irreális alkatú ideálok (túl sovány, túl izmos test), az erőteljes reklámtevékenység tovább fokozzák a fogyasztók elégedetlenségét saját testükkel szemben. Nincs ez másként a megkérdezett sportolók esetében sem. Az étrend-kiegészítők gyártói és forgalmazói nem csupán felhívják és hangsúlyozzák a fogyasztók figyelmét alkatuk hibáira (túl sovány, túlsúlyos, nem elég izmos, stb.), hanem megoldást is kínálnak a vélt- vagy valós problémákra. Tömegnövelőt a vékony testalkatúaknak, edzés előtti formulákat a keményen edzeni szándékozóknak, fehérjét a nagyobb izomtömegre vágyóknak, zsírégetőt a túlsúlyosaknak, stb., minden problémára van megoldási javaslatuk. Egy olyan jól jövedelmező iparág szemlélői lehetünk, 
amely épít az egyén önbizalmának hiányára, kételyeire és félelmeire. A saját testalkatában bizonytalankodó fogyasztó potenciális vásárlót jelent az étrend-kiegészítők gyártói számára, melyre kérdőívünk további kérdéseire adott válaszai egyértelműen rávilágítottak. Minél inkább elbizonytalanodott a fogyasztó, ez a gyártó számára annál inkább kedvező, a vásárlás valószínűsége nagyobb. A képlet marketing szempontból egyszerü, hívjuk fel fogyasztó figyelmét testének tökéletlenségére, világítsunk rá a problémára és kínáljunk erre megoldást is. A fogyasztóvédelem intézménye tipikusan ezeket a fogyasztói csoportokat védi az aktív és passzív fogyasztóvédelmi eszközök segítségével, a vállalati marketingaktivitással szemben. Jelenlegi példánk, az étrendkiegészítők, kommunikációjának szabályozása gyenge lábakon áll, lényegi korlátozással nem kell szembesülniük az étrend-kiegészítők gyártóinak, forgalmazóinak. Kutatásunk eredményeképpen nem az aktív jogi szabályozás szigorítása mellett állunk ki, nem ez a hosszú távú megoldás. Rövid távon eredményeket hozhat, azonban a fogyasztói tudatosság hosszútávú és tartós erősítésében a passzív eszközök hatásosabbak.

\section{Köszönetnyilvánítás}

„A publikáció elkészítését az EFOP-3.6.1-16-2016-00022 számú projekt támogatta. A projekt az Európai Unió támogatásával, az Európai Szociális Alap társfinanszírozásával valósult meg."

\section{Hivatkozott források}

[1.] Ábrahám I. - Jambrik M. - John B. - Németh A. - Franczia N. - Csenki L. (2017): A testképtől a testképzavarig. Orvosi hetilap, Vol. 158. No. 19. 723-730. o. DOI: $10.1556 / 650.2017 .30752$

[2.] Altabe, M. (1998): Ethnicity and body image: Quantitative and qualitative analysis. International Journal of Eating Disorders, Vol. 23. No. 2. 153159. p. DOI:

10.1002/(SICI)1098-108X(199803)23:2<153::AID-EAT5>3.0.CO;2-I

[3.] Bird, E. L. - Halliwell, E. - Diedrichs, P. C. - Harcourt, D. (2013): Happy being me in the UK: A controlled evaluation of a school-based body image intervention with pre-adolescent children. Body Image, Vol. 10. No. 3. 326-334. p. DOI: $10.1016 /$ j.bodyim.2013.02.008

[4.] Brudzynski L. - Ebben, W. (2010): Body image as a motivator and barrier to exercise participation. International Journal of Exercise Science, Vol. 3. No. 1. 14-24. p. 
[5.] Campbell A. - Hausenblas H. A. (2011): Effects of exercise interventions on body image: A Meta-analysis. Journal of Health Psychology, Vol. 14. No 6. 780-793. p. DOI: $10.1177 / 1359105309338977$

[6.] Cash T. F. - Melnyk S. E. - Hrabosky J. I. (2004): The assessment of body image investment: An extensive revision of the Appearance Schemas Inventory. International Journal of Eating Disorders, Vol. 35. No. 3. 305-316. p. DOI: $10.1002 /$ eat. 10264

[7.] Coelho, C. G. - Giatti, L. - Molina, M. D. - Nunes, M. A. - Barreto, S. M. (2015): Body image and nutritional status are associated with physical activity in men and women: The ELSA-Brazil study. International Journal of Environment Research and Public Health, Vol. 12. No. 6. 6179-6196. p. DOI: $\underline{10.3390 / \text { ijerph120606179 }}$

[8.] Coelho, E. M. - Fonseca, S. C. - Pinto, G. S. - Mourão-Carvalhal, M. I. (2016): Factors associated with body image dissatisfaction in Portuguese adolescents: obesity, sports activity and TV watching. Motricidad Ediçóes, Vol. 12, No. 2. 18-26. p. DOI: $10.6063 /$ motricidade.6277

[9.] Cronan, M. K. - Scott, D. (2008): Triathlon and women's narratives of bodies and sport. Leisure Sciences, Vol. 30. 17-34. p. DOI: $\underline{10.1080 / 01490400701544675}$

[10.] Csabai M. (2019): Az önelfogadás kihívásaitól a testpozitív mozgalmakig A pozitív pszichológia testképei. Magyar Pszichológiai Szemle, 74. évf. 3. sz. 361-373. o. DOI: $\underline{10.1556 / 0016.2019 .74 .3 .6}$

[11.] Dewi R. C. - Bambang W. (2019): Energy intake, body image, physical activity and nutritional status of teenagers. Journal of Public Health in Africa, Vol. 10. No. 1. (Spl). 8689. p. DOI: 10.4081/jphia.2019.1194

[12.] Eurostat (2019): Persons performing physical activity outside working time by duration in a typical week, educational attainment level, sex and age, forrás:

http://bit.ly/eurostat_2017_persons_performing_physical_activity_outside_working_time, Last update: 18.12.2019, Last access: 22.01.2020

[13.] Fountoulakis, C. - Grogan, S. (2014): An investigation of the links between body image and exercise participation. Sport \& Exercise Psychology Review, Vol. 10. No. 3. 19-30. p.

[14.] Keyes, C. L. M. - Shmotkin, D. - Ryff, C. D. (2002): Optimizing wellbeing: The empirical encounter of two traditions. Journal of Personality and Social Psychology, Vol. 82. No. 6. 1007-1022. p. DOI: 10.1037/0022$\underline{3514.82 .6 .1007}$

[15.] Kruger, J. - Lee, C. D. - Ainsworth, B. E. - Macera, C. A. (2008): Body size satisfaction and physical activity levels among men and women. Obesity, Vol. 16. No. 8. 1976-1979. p. DOI: 10.1038/oby.2008.311 
[16.] KSH (2015a). Európai lakossági egészségfelmérés, 2014. Statisztikai tükör, 2015/29. sz. forrás:

https://www.ksh.hu/docs/hun/xftp/stattukor/elef14.pdf

[17.] KSH (2015b). Európai lakossági egészségfelmérés, 2014, Táblázatok, Sporttevékenység, https://www.ksh.hu/elef/archiv/2014/tablak/elef_osszefoglalo_adatok_09.xls

[18.] KSH (2018): Boros J. - Györke J. - Pásztorné S. E. - Szabó Zs. K. (2018): A 2014-ben végrehajtott Európai lakossági egészségfelmérés eredményei. Összefoglaló adatok. Budapest, Központi Statisztikai Hivatal, 64 o.

Forrás: https://www.ksh.hu/docs/hun/xftp/idoszaki/elef/elef2014_osszefoglalo.pdf, 64 p.

[19.] LeComte, R. S. - Michael, J. S. - David P. J. (2020): Independent Effects of Ideal Body Image Valuation and Delay Discounting on Proximal and Typical Levels of Physical Activity. The Psychological Record, Vol. 70. No. 4. 75-82. p. DOI: 10.1007/s40732-019-00369-y

[20.] Leng, H. K. - Phua, Y. X. P. - Yang, Y. (2020): Body Image, Physical Activity and Sport Involvement: A Study on Gender Differences. Physical Culture and Sport, Studies and Research, Vol. 85. No. 1. 40-49. p. DOI: 10.2478/pcssr-2020-0005

[21.] Liechty, T. - Sveinson, K. - Willfong, F. - Evans, K. - (2015): It Doesn't Matter How Big or Small You Are... There's a Position For You: Body Image Among Female Tackle Football Players. Leisure Sciences, Vol. 37. No.2. 109-124. p. DOI: $\underline{10.1080 / 01490400.2014 .980591}$

[22.] Littleton, H. L. - Ollendick, T. (2003): Negative body image and disordered eating behaviour in children and adolescents: what places youth at risk and how can these problems be prevented?. Clinical Child and Family Psychology Review, Vol. 6. No.1. 51-66. p.

DOI: $10.1023 / \mathrm{A}: 1022266017046$

[23.] Lunde, C. - Gattario, K. H. (2017): Performance or appearance? Young female sport participants' body negotiations. Body Image, Vol. 21., 8189.p. DOI: $10.1016 /$ j.bodyim.2017.03.001

[24.] OECD (2017): OECD Reviews of Health Systems: Peru 2017. Paris, Paris OECD Publishing, 172 p. DOI: $10.1787 / 9789264282735$-en

[25.] Peráčková, J. - Chovancová, A. - Kukurová, K. - Plevková, L. (2018): Selfevaluation of body image in sport active and sport inactive adolescent girls. Acta Gymnica, Vol. 48. No. 3. 109-114. p. DOI: 10.5507/ag.2018.014

[26.] Prichard, I. - Tiggemann, M. (2005): Objectification in fitness centers: Self-objectification, body dissatisfaction, and disordered eating in aerobic instructors and aerobic participants. Sex Roles, Vol. 53. No. 1-2. 19-28. p. DOI: $\underline{10.1007 / s 11199-005-4270-0}$ 
[27.] Prichard, I. - Tiggemann, M. (2008): Relations among exercise type, selfobjectification, and body image in the fitness centre environment: The role of reasons for exercise. Psychology of Sport and Exercise, Vol. 9. No. 6. 855-866. p. DOI: $10.1016 / j$.psychsport.2007.10.005

[28.] Sabiston, C. M. - Lucibello, K. M. - Kuzmochka-Wilks, D. - Koulanova A. - Pila E. - Sandmeyer-Graves, A. - Maginn D. (2020): What's a coach to do? Exploring coaches'perspectives of body image in girls sport. Psychology of Sport and Exercise, Vol. 48.9 p.

DOI: $10.1016 /$ j.psychsport.2020.101669

[29.] Schmalz, D. L. - Deane, G. D. - Birch, L. L. - Davison, K. K. (2007): A longitudinal assessment of the links between physical activity and self-esteem in early adolescent non-Hispanic females. Journal of Adolescent Health, Vol. 41. No. 6. 559-565. p.

[30.] DOI: $10.1016 / j$ j.jadohealth.2007.07.001

[31.] Slater, A. - Tiggemann, M. (2011): Gender differences in adolescent sport participation, teasing, self-objectification and body image concerns. Journal of Adolescence, Vol. 34. No. 3. 455-463. p.

DOI: $10.1016 /$ j.adolescence.2010.06.007

[32.] Smolak L. (2002): Body image development in children. In: Cash, T. F. Pruzinsky, T. (Eds.): Body image: A handbook of theory, research, and clinical practice. ( $1^{\text {st }}$ edition) New York, Guilford Press, 65-74. p.

[33.] Smolak L. (2011): Body images development in childhood. In: Cash, T. F. - Smolak, L. (Eds.): Body image. A handbook of science, practice and prevention. (2 $2^{\text {nd }}$ edition) New York, Guilford Press, 67-75. p.

[34.] Swami, V. - Weis, L. - Barron, D. - Furnham, A. (2018): Positive body image is positively associated with hedonic (emotional) and eudaimonic (psychological and social) well-being in British adults. The Journal of Social Psichology, Vol. 158. No. 5. 541-552. p. DOI: $\underline{10.1080 / 00224545.2017 .1392278}$

[35.] Tosseli, S. - Spiga, F. (2017): Sport practice, physical structure, and body image among university students. Journal of Eating Disorders, Vol. 5. Paper 31.

DOI: $\underline{10.1186 / s 40337-017-0163-1}$

[36.] Tylka, T. L. (2011): Positive psychology perspectives on body image. In: Cash, T. F. - Smolak, L. (Eds.): Body image: A handbook of science, practice and prevention ( $2^{\text {nd }}$ edition). New York, Guilford Press, 56-64. p.

[37.] Tylka, T. L. (2012): Positive psychology perspectives on body image. In: T. F. Cash (Ed.): Encyclopedia of body image and human appearance, Vol. 2. San Diego, Academic Press, 657-663. p. DOI: $10.1016 / \mathrm{B} 978-0-12-384925-0.00104-8$ 
[38.] Tylka, T. L. - Wood-Barcalow, N. L. (2015). What is and what is not positive body image? Conceptual foundations and construct definition. Body Image, Vol. 14 118-129. p. DOI: 10.1016/j.bodyim.2015.04.001

[39.] Wardle, J. - Bindra, R. - Fairclough, B. - Westcombe, A. (1993): Culture and body image: Body perception and weight concern in young Asian and Caucasian British women. Journal of Community \& Applied Social Psychology, Vol. 3. No. 3. 173-181. p. DOI: 10.1002/casp.2450030302

\section{Szerzők:}

\section{Szücs Róbert Sándor}

Dr. habil. (PhD., Habilitáció)

Debreceni Egyetem

Gazdaságtudományi Kar, Marketing és Kereskedelem Intézet, főiskolai docens szucs.robert.sandor@econ.unideb.hu

\section{Pólya Éva}

Dr. (PhD.)

Debreceni Egyetem

Gazdaságtudományi Kar, Marketing és Kereskedelem Intézet, főiskolai docens polya.eva@econ.unideb.hu

\section{Szakály Zoltán}

Prof. Dr. habil. (CSc., Habilitáció)

Debreceni Egyetem

Gazdaságtudományi Kar, Marketing és Kereskedelem Intézet, egyetemi tanár szakaly.zoltan@econ.unideb.hu 